\title{
Fizyoterapi Ve Rehabilitasyon Bölümü Öğrencilerinin Mesleğe Yönelik Umutsuzluk Düzeyleri ve İlişsili Parametreler
}

Levels of Hopelessness And Related Parameters for Occupation in Students at Division of Physiotherapy and Rehabilitation

\author{
Ebru KAYA MUTLU ${ }^{\text {iD }}$ Arzu RAZAK ÖZDINÇLER ${ }^{\text {(iD }}$ Tansu BIRINCIc $^{\text {iD }}$
}

ÖZET Amaç: Fizyoterapi ve Rehabilitasyon Bölümü’nde öğrenim gören öğrencilerin mesleğe yönelik umutsuzluk düzeylerini belirlemek ve öğrencilerin umutsuzluk düzeylerinin sosyodemografik özellikler, mesleki farkındalık, mesleki kaygı, mesleki yeterlilik ve bölüm memnuniyeti ile ilişkisini incelemekti. Gereç ve Yöntemler: Çalışmaya İstanbul Üniversitesi, Sağlık Bilimleri Fakültesi Fizyoterapi ve Rehabilitasyon Bölümü'nde eğitim gören 364 öğrenci dahil edildi. Katılımcıların 115'i 1. sınıf, 95'i 2. sinıf, 94'ü 3. sınıf ve 60'1 4. sınıf öğrencisi idi. Katılımcıların sosyodemografik ve mesleğe yönelik bilgileri tarafımızca hazırlanan "Kişisel ve Mesleğe Yönelik Bilgi Toplama Formu" ile sorgulandı. Umutsuzluk düzeyi "Beck Umutsuzluk Ölçeği (BUÖ)" kullanılarak değerlendirildi. Bulgular: BUÖ sonuçlarına göre Fizyoterapi ve Rehabilitasyon Bölümü öğrencilerinin "hafif umutsuzluk" düzeyinde oldukları belirlendi. BUÖ ile cinsiyet arasında $(\mathrm{p}=0.002, \mathrm{r}=-0.15)$ ve BUÖ ile aile gelir düzeyi arasında negatif ilişki bulundu ( $\mathrm{p}=0.86 \mathrm{r}=-0.009)$. BUÖ ile mezun sayısının artışı, iş bulma kaygısı, mesleki saygınlık, tekrar tercih etme durumu ve bölüm memnuniyeti arasında anlamlı ilişki bulundu $(p<0.05)$. Ayrıca, öğrencilerin son sınıfta iş bulma kaygılarının diğer sınıflara göre istatistiksel olarak daha yüksek olduğu $(\mathrm{p}=0.01)$ ve son sınıfta mesleki olarak daha yeterli hissettikleri saptandı $(\mathrm{p}=0.001)$. Sonuç: Fizyoterapi ve Rehabilitasyon bölümü öğrencilerinin mesleğe yönelik umutsuzluk yaşadıkları ve umutsuzluğa cinsiyet, aile gelir düzeyi, artan mezun sayısı, iş bulma endişesi, mesleki saygınlık, bölümden memnun olmama gibi birçok faktörün etkili olduğu görülmüsşür. Öğrencilerin akademik başarısının, mesleki yeterliliğinin ve bölüm memnuniyetinin arttırılması için öğretim elemanlarının desteğinin alınması gerektiği ve istihdam artışı ile orantılı olarak mezun verilmesinin iş bulma imkanlarını arttıracağı düşünmekteyiz.

Anahtar Kelimeler: umutsuzluk, fizyoterapi, memnuniyet, eğitim

\begin{abstract}
Objective: The aim of this study was to determine hopelessness levels of physiotherapy students and to examine its relation with sociodemographic.characteristics, professional awareness, occupational anxiety, professional competence and satisfaction. Methods: A total of 364 physiotherapy students studying at Istanbul University were enrolled in this study. One-hundred-fifteen of the participants were $1^{\text {st }}$ grade, 95 were $2^{\text {nd }}$ grade, 94 were $3^{\text {rd }}$ grade and 60 were $4^{\text {th }}$ grade students. Participants' sociodemographic and occupational information was questioned by the "Personal and Occupational Information Form". The level of hopelessness was assessed using "Beck Hopelessness Scale (BHS)".Results: According BHS results, physiotherapy students were found to be in the "slight hopelessness" level. BHS was negatively correlated with gender $(\mathrm{p}=0.002, \mathrm{r}=-0.15)$, and family income ( $\mathrm{p}=0.86 \mathrm{r}=-0.009$ ). There was a significant relationship between increasing number of graduates, worries about employment, professional dignity, re-preference status and satisfaction $(\mathrm{p}<0.05)$. In addition, it was found that students were more likely to be anxious about getting a job $(\mathrm{p}=0.01)$ and felt more confident professionally in the final grade $(\mathrm{p}=0.001)$. Conclusion: It has been found that physiotherapy students are hopeless for the profession and it is influenced by many factors such as gender, level of family income, increasing number of graduates, worries about employment, professional dignity, dissatisfaction with the education. We think that the support of the academicians should be taken to increase the academic success of the students, professional competence and satisfaction of the department, and the number of graduation in proportion to increase in employment will increase the employment opportunities.
\end{abstract}

Keywords: hopelessness, physiotherapy, satisfaction, education

\section{Giriș}

Umut, gelecek ile ilgili bir amacı gerçekleştirmek için olumlu beklentilere veya duygulara sahip olma durumudur $(1,2)$. Umutlu insanlar geleceğe

yönelik hedeflerine ulaşmada yeteneklerini kullanma yönelimindedirler ve dolayısıyla hedefe yönelik davranışlarda bulunurlar(1).

Geliș Tarihi/Received: 08-08-2017 / Kabul Tarihi/Accepted:25-08-2017

a Yard. Doç. Dr. İ.Ü. Sağlık Bilimleri Fakültesi, Fizyoterapi ve Rehabilitasyon Bölümü, İstanbul, ORCID ID:0000-0002-8595-5513

b Prof. Dr. İ.Ü. Sağlık Bilimleri Fakültesi, Fizyoterapi ve Rehabilitasyon Bölümü, İstanbul, ORCID ID:0000-0003-1783-3992

c Uzman Fizyoterapist İ.Ü. Sağlık Bilimleri Fakültesi, Fizyoterapi ve Rehabilitasyon Bölümü, İstanbul, ORCID ID:0000-00027993-3254

Sorumlu yazar /Correspondence: Yrd. Doç. Dr. Ebru Kaya Mutlu, İ.Ü. Sağlık Bilimleri Fakültesi, Fizyoterapi ve Rehabilitasyon Bölümü, İstanbul. fztebrukaya@hotmail.com, 
Umudun karşıtı olan umutsuzluk ise, kişinin kendi içinde bulunduğu fiziksel, zihinsel veya toplumsal durumun düzelemeyeceğine ilişkin genel ruh halidir (3). Kişide umutsuzlukla ilgili değersizlik, çaresizlik, mutsuzluk, kararsızlık, eyleme geçememe, işlerini sürdürememe ve suçluluk duyguları da ortaya çıkar (4).

Üniversite dönemi, kişisel, sosyal, mesleki ve ekonomik pek çok sorunla başa çıkmayı gerektiren bir dönemdir. Bu dönemde yaşanan önemli sorunlardan birisi de umutsuzluktur (1, 5, 6). Literatürde, umutsuzluk düzeyini ve etkileyen faktörleri ortaya koyan birçok çalışmaya rastland1. Gündoğar ve ark. (7) üniversite öğrencilerinin yaşam doyumlarını etkileyen faktörleri inceledikleri bir çalışmada bireyin umutsuzluk düzeyi, eğitim durumu, iş beklentisi ve istediği bölümde okuma isteğinin yaşam doyumunu etkilediğini belirlemişlerdir. Aydın ve ark. (8) yaptıkları bir çalışma sonucunda öğrencilerin yaşadıkları umutsuzluk düzeyinde, akademik başarı durumu, iş bulma endişesi, okuduğu bölüm gibi faktörlerin etkili olduğunu ortaya koyarken, Oğuztürk ve ark. (9) tarafından yapılan Hukuk Fakültesi ve Edebiyat Fakültesi ögrencilerinin umutsuzluk düzeyinin değerlendirildiği bir çalışmanın sonucunda öğrencilerin umutsuzluk düzeyi ve öğrenim görülen bölüm bakımından anlamlı bir fark bulunmamıştır. Yalçın ve ark. (10) ebelik ve hemşirelik son sınıf öğrencilerine yaptıkları çalışmalarında öğrencilerin mezun olduklarında iş bulma olasılığının yüksek olduğunu bilmelerinin gelecek kaygılarını azalttığını ve umutlu olduklarını bildirmişlerdir.

Yüksekokul olarak veya Sağlık Bilimleri Fakültelerinin içinde yer alan Fizyoterapi ve Rehabilitasyon bölümü öğrencilerinin umut ve umutsuzluk düzeyleri ile ilgili bir çalı̧̧maya rastlanmamıştır. Ayrıca, literatüre bakıldığında üniversite öğrencilerinin umutsuzluk düzeyinin sosyodemografik özelliklerle ilişkisini inceleyen araştırmalara rastlanmış fakat mesleki farkındalık ve mesleki yeterlilik algısının öğrencilerin umut düzeyleri ile ilişkisine bakan bir araştırmaya rastlanmamıştır.

Çalışmamızın amacı, Fizyoterapi ve Rehabilitasyon Bölümü'nde öğrenim gören öğrencilerin mesleğe yönelik umutsuzluk düzeylerini belirlemek ve öğrencilerin umutsuzluk düzeylerinin sosyodemografik özellikler, mesleki farkındalık, mesleki kaygı, mesleki yeterlilik ve bölüm memnuniyeti ile ilişkisini incelemektir.

\section{Gereç ve Yöntemler}

Bu çalışma, 01 Şubat- 30 Haziran 2016 tarihleri arasında genel tarama modellerinden anlık durum saptama yönetimi ile İstanbul Üniversitesi (İ.Ü.) Sağlık Bilimleri Fakültesi Fizyoterapi ve Rehabilitasyon Bölümü'nde yapıldı. Araştırmamızın örneklemine ulaşmak için İ.Ü. Sağlık Bilimleri Fakültesi Dekanlığından üst yazı ile izin alındı. Çalışmaya, 20-30 yaşlarında, çalışmaya katılmaya gönüllü olan, İ.Ü. Sağlık Bilimleri Fakültesi, Fizyoterapi ve Rehabilitasyon öğrencileri dahil edildi. Tam zamanlı bir işte çalışan ve verilen anketlerin eksik dolduran öğrenciler çalışmaya dahil edilmedi.

Çalışma için etik kurul onayı Bakırköy Dr. Sadi Konuk Eğitim ve Araştırma Hastanesi, Klinik Araştırmalar Etik Kurul'undan alındı. Araştırmaya katılan öğrenciler çalışma hakkında bilgilendirilerek imzalı onamları alındı ve "Helsinki Deklerasyonu'na" uygun olarak araştırmamız yürütüldü (Etik Kurul No: 2016221).

\section{Veri Toplama Araçları}

Gönüllü olarak çalışmaya katılmayı kabul eden öğrencilerden araştırmacılar tarafından hazırlanan "Kişisel ve Mesleğe Yönelik Bilgi Toplama Formu" ve Beck ve ark tarafindan geliştirilen "Beck Umutsuzluk Ölçeği” ni doldurmaları istendi.

Kişisel ve Mesleğe Yönelik Bilgi Toplama Formu: Form sosyodemografik ve mesleğe yönelik bilgiler olarak iki bölümden oluşturuldu. Kişisel bilgiler bölümünde yaş, cinsiyet, medeni durum, giriş yılı, tercih sırası, ailenin aylık geliri, yaşadığı yer, annenin-babanın eğitim ve mesleki durumu, engel durumu sorguland. Mesleki bölümde mesleki farkındalık; kontenjan sayısının artması, mezun sayısının ihtiyaçtan fazla olması, istihdam sayısının yeterliliği, eğitim süresinin yeterliliği, meslek odasının olup/olmadığı, mesleği ile ilgili derneğin olup olmadığ mesleğin akreditasyonu olup/olmadığı evet/hayır sistemiyle sorguland. Ayrica mesleki kayg1, mesleki yeterlilik ve bölüm memnuniyeti ile ilgili 5 adet soru oluşturuldu ve 5'li likert sistemi ile sorguland. Mesleki kaygıya yönelik sorular; 1Mezun olunca iş bulamama kaygınız var mı? Kaygılı değilim ( ) Biraz kaygılıyım ( ) Kaygılıyım ( ) Çok kaygılıyım ( ) Bilmiyorum ( ); 2- Mesleğinizin toplum tarafindan yeterli saygıyı gördüğünü düşünüyor musunuz?: Hayır düşünmüyorum ( ) Biraz düşünüyorum ( ) Düşünüyorum ( ) Çok düşünüyorum ( ) Bilmiyorum ( ) idi. Mesleki yeterliliğe yönelik 
soru; 1- Kendinizi mesleki açıdan yeterli hissediyor musunuz?: Yeterli değilim ( ) Biraz yeterliyim ( ) Yeteliyim ( ) Çok yeterliyim ( ) Bilmiyorum ( ) idi. Bölüm memnuniyetine yönelik sorular 1- Tekrar tercih yapacak olsanız bu bölümü seçer misiniz?: Kesinlikle Hayır ( ) Hayır ( ) Evet ( ) Kesinlikle evet ( ) Bilmiyorum ( ); 2- Yaptığınız bölüm seçiminden memnun musunuz?: Memnun değilim () Biraz memnunum ( ) Memnunum ( ) Çok memnunum ( ) Bilmiyorum ( ) idi.

Beck Umutsuzluk Ölçeği (BUÖ): "Beck Umutsuzluk Ölçeği”, Beck ve ark (11) tarafından bireyin geleceğe yönelik olumsuz beklenti düzeyini belirlemek amaciyla geliş̧irilmiştir. Ölçek 20 maddeden oluşmaktadır ve ölçeğin Türkçe geçerlilik ve güvenilirlik çalışması yapılmıştır (12, 13). Kişinin kendini değerlendirmesi şeklinde bir ölçek olmakla birlikte ergen ve yetişkinlerde uygulanmaktadır. Anketin doldurmasinda zaman sinırlaması yoktur ve uygulanması kolaydır. Ankete katılan kişiden kendisi için uygun olan ifadeleri "evet", uygun olmayanları ise "hayır" olarak işaretlemesi istenmektedir. Maddelerin 11 tanesinde "evet" seçeneği; 9 tanesinde ise "hayır" seçeneği 1 puan alır. $1,3,5,6,8,10,13,15$ ve 19 . sorularda "hayır"; 2, 4, 7, 9, 11, 12, 14, 16, 17, 18 ve 20. sorularda ise "evet" yanıtı için " 1 " puan verilir. $\mathrm{Bu}$ sorulara aksi verilen cevaplarda da "0" verilmektedir. Ölçekten 0 ile 20 arası puan alınabilmektedir. Ölçekten alınan puanların yüksekliği, bireydeki umutsuzluk düzeyinin yüksek olduğunu gösterir. Ayrıca, BUÖ'nün toplam skoru dört grup içinde sınıflandırılır; 0 ile 3 arası umutlu, 4 ile 8 arası hafif umutsuzluk, 9 ile 14 arasi orta seviyede umutsuzluk, 15 ile 20 arası ileri derecede umutsuzluk (14).

\section{İstatistiksel Analiz}

Elde edilen verilerin analizinde SPSS paket istatistik programının 21.0 (Statistical Package for the Social Sciences Inc; Chicago, IL, ABD) sürümü kullanıldı. Verilerin normal dağılıma uygunluğunun tespiti için "Shapiro Wilk Testi" kullanıldı. Tüm veriler normal dağılıma uyduğu için analizde parametrik testler uygulandı. Sayısal veriler aritmetik ortalama \pm standart sapma $(\mathrm{X} \pm \mathrm{SD})$ olarak ifade edildi. Kategorik veriler $\mathrm{n}(\%)$ şeklinde gösterildi. Kategorik verilere göre sınıfların karşılaştırılması ki-kare test ile yapıldı. Öğrencilerin, yaş, gelecek kaygısı ve umutsuzluk puanları tek yönlü varyans analizi "ANOVA" ile karşılaştırıldı. Parametreler arası ilişki düzeyi Pearson korelasyon analizi kullanılarak yapıldı. Tüm analizlerde $\mathrm{p}<0.05$ (iki yönlü) değerler istatistiksel olarak anlamlı kabul edildi.

\section{Bulgular}

2015- 2016 eğitim öğretim döneminde İ.Ü. Sağlık Bilimleri Fakültesi, Fizyoterapi ve Rehabilitasyon Bölümü'nde öğrenim gören 120 kişi 1. sınıf, 102 kişi 2. sınıf, 96 kişi 3. sınıf ve 70 kişi 4. sınıf olmak üzere toplam 388 öğrenci öğrenim görmekteydi. 15 öğrenciye ulaşılamaması ve 9 öğrencinin de anketleri eksik doldurması nedeniyle çalışmaya toplam 364 öğrenci katıldı. Araştırmaya katılan gönüllülerin sosyodemografik özelikleri Tablo 1'de gösterildi. Öğrencilerin 355'inin (\%97.5) medeni durumu bekâr iken 9 (\%2.5) kişi ise evli idi. Araştırmaya katılan öğrencilerin babalarının ve annelerinin eğitim durumları karşılaştırıldığında sınıflar arasında istatistiksel olarak anlamlı bir fark olmadığ 1 saptand 1 (sırasiyla; $\mathrm{p}=0.47$ ve $\mathrm{p}=0.06$ ). Öğrencilerin Fizyoterapi ve Rehabilitasyon Bölümü'ne yerleştiği tercih sıraları 1 ile 30. sıra arasında değişmektedir ve sınıfların tercih ortalamaları Şekil 1'de gösterilmektedir.

Şekil 1. Öğrencilerin Fizyoterapi ve

Rehabilitasyon Bölümü'nün Tercih Sırası

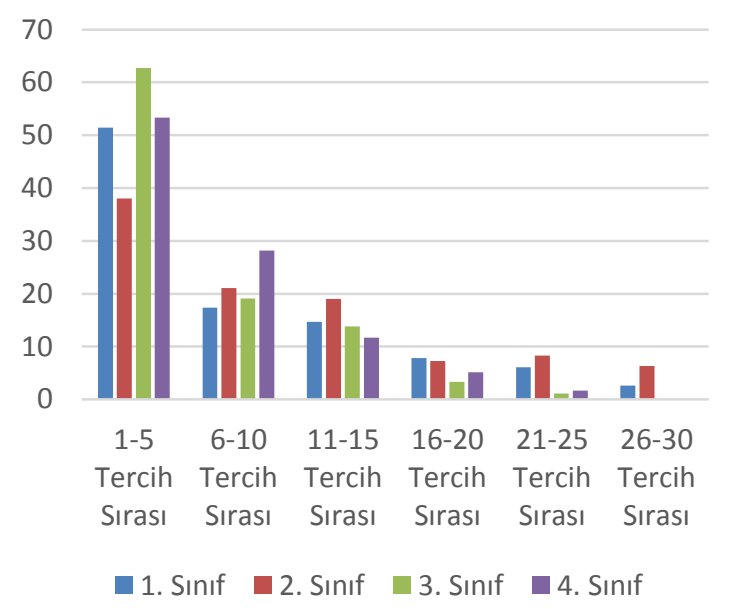

Öğrencilerin mesleki farkındalık ile ilgili sorulara verdikleri cevaplar Tablo 2' de gösterildi. Kontenjan artışının öğrenciler üzerindeki endişe durumunun oranına bakıldığında 1.Sınıf' in \%90.4, 2. Sinif' 1 \% \%91.6, 3.Sinif'1n \%90.4 ve son sınıfın \%91.7 olduğu belirlendi. Tüm sınıfların endişeli olduğu ve sınıflar arasında istatistiksel olarak anlamlı bir fark bulunmadı $(\mathrm{p}=0.80)$. Öğrencilerin meslek ile ilgili eğitim süresi, meslek odas1, dernek ve akreditasyon ile ilgili olarak sinıflar arasında istatistiksel olarak bilgi 


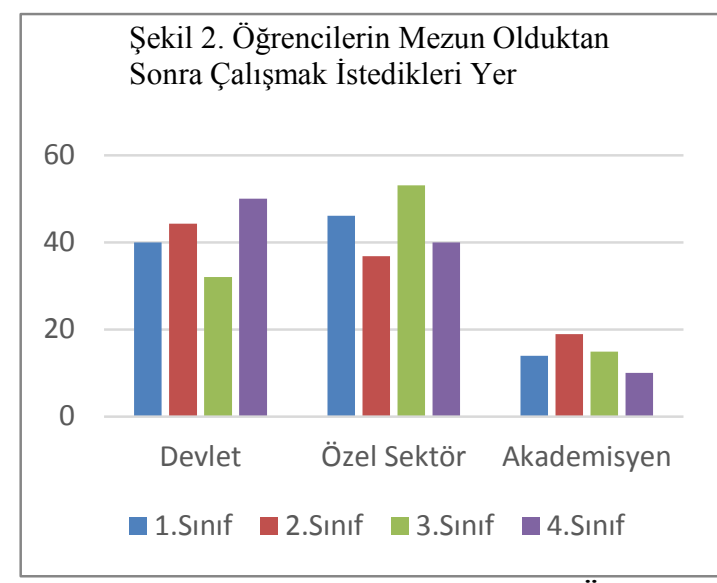

farklılığı olduğu bulundu $(\mathrm{p}<0.05)$. Öğrencilerin mezun olunca çalışmak istedikleri kurumlar Şekil 2'de gösterilmiştir ve sınıflar arasında çalışma yerleri bakımından istatistiksel olarak anlamlı bir fark bulunmadi $(\mathrm{p}=0.17)$.

Tablo 3'de öğrencilerin mezun olunca iş bulamama kaygıları, mesleğin toplum tarafından yeterli saygıyı görüp/görmediği, kendisini mesleki açıdan yeterli hissedip/hissetmediği, tekrar tercih yapacak olsa bu bölümü seçip/seçmeyeceği ve yaptığı bölüm seçiminden memnun olup/olmadığ ile ilgili verdiği cevaplar gösterilmektedir. Öğrencilerin son sınıfta iş bulma kaygılarının diğer sınıflara göre istatistiksel olarak daha yüksek olduğu $(\mathrm{p}=0.01)$ ve son sinifta mesleki olarak daha yeterli hissettikleri saptand $1(\mathrm{p}=0.001)$ (Tablo 3$)$.

BUÖ verilerine bakıldığında 1.sınıf öğrenci sonuçlarının toplam ortalama değeri $5.90 \pm 4.14$, 2. sınıf öğrenci sonuçlarının toplam ortalama değeri $4.93 \pm 3.87,3$. sınıf öğrenci sonuçlarının toplam ortalama değeri $5.14 \pm 3.67$ ve 4 . sinıf öğrenci sonuçlarının toplam ortalama değeri $6.58 \pm 4.82$ 'dir. BUÖ toplam ve alt gruplarında sinıflar arasında istatistiksel olarak anlamlı fark bulunmadi ( $p>0.05)$. Ancak, Fizyoterapi ve Rehabilitasyon Bölümü öğrencilerinin "hafif umutsuzluk" düzeyinde oldukları belirlendi.

Tablo1. Öğrencilerin Sosyodemografik Bilgileri

\begin{tabular}{|c|c|c|c|c|c|}
\hline & $\begin{array}{l}\text { 1. Sinif } \\
(\mathrm{n}=115)\end{array}$ & $\begin{array}{l}\begin{array}{l}\text { 2. Sinif } \\
(\mathrm{n}=95)\end{array}\end{array}$ & $\begin{array}{l}\text { 3. Sinıf } \\
(\mathrm{n}=94)\end{array}$ & 4. $\operatorname{Sin} 1 f(n=60)$ & $\mathrm{p}$ \\
\hline \multicolumn{6}{|l|}{ Yaş (y1l) } \\
\hline & $20.31 \pm 2.17$ & $21.02 \pm 1.48$ & $21.80 \pm 1.67$ & $22.83 \pm 1.38$ & 0.001 \\
\hline & $\mathrm{n}(\%)$ & $\mathrm{n}(\%)$ & $\mathrm{n}(\%)$ & $\mathrm{n}(\%)$ & \\
\hline \multicolumn{6}{|l|}{ Cinsiyet } \\
\hline Kadın & $66(57.4)$ & $64(67.4)$ & $49(52.1)$ & $29(48.3)$ & 0.07 \\
\hline Erkek & $49(42.6)$ & $31(32.6)$ & $45(47.9)$ & $31(51.7)$ & \\
\hline \multicolumn{6}{|l|}{ Medeni Durum } \\
\hline Evli & $6(5.2)$ & $1(1.1)$ & $1(1.1)$ & $1(1.7)$ & 0.15 \\
\hline Bekar & $109(94.8)$ & $94(98.9)$ & $93(98.9)$ & $59(98.3)$ & \\
\hline \multicolumn{6}{|l|}{ Ailenin Geliri } \\
\hline $0-1300$ & $18(15.7)$ & $16(16.8)$ & $11(11.7)$ & $9(15)$ & \\
\hline $1300-2000$ & $38(33)$ & $33(34.7)$ & $33(35.1)$ & $16(26.7)$ & 0.49 \\
\hline $2000-5000$ & $44(38.3)$ & $33(34.7)$ & $42(44.7)$ & $27(45)$ & \\
\hline 5000 ve üstü & $15(13)$ & $13(13.7)$ & $8(8.5)$ & $8(13.3)$ & \\
\hline \multicolumn{6}{|l|}{ Yaşadığı Yer } \\
\hline Aile ile & $43(37.4)$ & $32(33.7)$ & $34(36.2)$ & $19(31.7)$ & \\
\hline Yurtta & $49(42.6)$ & $37(38.9)$ & $33(35.1)$ & $17(28.3)$ & 0.05 \\
\hline Özel Ev & $18(15.7)$ & $17(17.9)$ & $24(25.5)$ & $22(36.7)$ & \\
\hline Akraba Yanı & $5(4.3)$ & $9(9.5)$ & $3(3.2)$ & $2(3.3)$ & \\
\hline \multicolumn{6}{|l|}{ Annenin Mesleği } \\
\hline Çalışmıyor & $75(65.2)$ & $68(71.6)$ & $76(80.9)$ & $45(75)$ & \\
\hline İşçi & $11(9.6)$ & $12(12.6)$ & $5(5.3)$ & $2(2.3)$ & 0.31 \\
\hline Memur & $13(11.3)$ & $7(7.4)$ & $5(5.3)$ & $8(13.3)$ & \\
\hline Emekli & $9(7.8)$ & $5(5.3)$ & $5(5.3)$ & $4(6.7)$ & \\
\hline Serbest Meslek & $7(6.1)$ & $3(3.2)$ & $3(3.2)$ & $1(1.7)$ & \\
\hline
\end{tabular}


Tablo 2. Öğrencilerin Mesleki Farkındalıklarına Göre Dağılımı

\begin{tabular}{|c|c|c|c|c|c|c|}
\hline & $\begin{array}{l}\text { Verilen } \\
\text { Cevap }\end{array}$ & $\begin{array}{l}\text { 1. Sinif } \\
(\mathrm{n}=115)\end{array}$ & $\begin{array}{l}\begin{array}{l}\text { 2. Sinif } \\
(\mathrm{n}=95)\end{array}\end{array}$ & $\begin{array}{l}\begin{array}{l}\text { 3. Sinif } \\
(\mathrm{n}=94)\end{array} \\
\end{array}$ & $\begin{array}{l}\begin{array}{l}\text { 4. Sinif } \\
(\mathrm{n}=60)\end{array} \\
\end{array}$ & $\mathrm{p}$ \\
\hline & & $\mathrm{n}(\%)$ & $\mathrm{n}(\%)$ & $\mathrm{n}(\%)$ & $\mathrm{n}(\%)$ & \\
\hline $\begin{array}{c}\text { Babanın Mesleği } \\
\text { Çalışmıor } \\
\text { İşçi } \\
\text { Memur } \\
\text { Emekli } \\
\text { Serbest Meslek }\end{array}$ & $\begin{array}{l}10(8.7) \\
30(26.1) \\
19(16.5) \\
42(36.5) \\
14(12.2)\end{array}$ & $\begin{array}{l}2(2.1) \\
20(21.1) \\
15(15.8) \\
42(44.2) \\
16(16.8)\end{array}$ & $\begin{array}{l}3(3.2) \\
23(24.5) \\
19(20.2) \\
33(35.1) \\
16(17.0)\end{array}$ & $\begin{array}{l}2(3.3) \\
10(16.7) \\
16(26.7) \\
29(48.3) \\
3(5)\end{array}$ & 0.11 & \\
\hline $\begin{array}{l}\text { Kontenjan artışı sizi } \\
\text { endişelendiriyor mu? }\end{array}$ & $\begin{array}{l}\text { Evet } \\
\text { Hayır }\end{array}$ & $\begin{array}{l}104(90.4) \\
11(9.6)\end{array}$ & $\begin{array}{l}87(91.6) \\
8(8.4)\end{array}$ & $\begin{array}{l}85(90.4) \\
9(9.6)\end{array}$ & $\begin{array}{l}55(91.7) \\
5(8.3)\end{array}$ & 0.80 \\
\hline $\begin{array}{l}\text { Mezun sayısı ihtiyaçtan fazla } \\
\text { mı? }\end{array}$ & $\begin{array}{l}\text { Evet } \\
\text { Hayır }\end{array}$ & $\begin{array}{l}95(82.6) \\
20(17.4)\end{array}$ & $\begin{array}{l}79(83.2) \\
16(16.8)\end{array}$ & $\begin{array}{l}68(72.3) \\
26(27.7)\end{array}$ & $\begin{array}{l}52(86.7) \\
8(13.3)\end{array}$ & 0.21 \\
\hline $\begin{array}{l}\text { Mesleğinizin istihdam sayısı } \\
\text { yeterli mi? }\end{array}$ & $\begin{array}{l}\text { Evet } \\
\text { Hayır }\end{array}$ & $\begin{array}{l}21(18.3) \\
94(81.7)\end{array}$ & $\begin{array}{l}12(12.6) \\
83(87.4)\end{array}$ & $\begin{array}{l}11(11.7) \\
83(88.3)\end{array}$ & $\begin{array}{l}2(3.3) \\
58(96.7)\end{array}$ & 0.09 \\
\hline $\begin{array}{l}\text { Mesleğinizin eğitim süresi } \\
\text { yeterli mi? }\end{array}$ & $\begin{array}{l}\text { Evet } \\
\text { Hayır }\end{array}$ & $\begin{array}{l}84(73) \\
31(27)\end{array}$ & $\begin{array}{l}40(42.1) \\
55(57.9)\end{array}$ & $\begin{array}{l}22(23.4) \\
71(75.6)\end{array}$ & $\begin{array}{l}31(51.7) \\
29(48.3)\end{array}$ & 0.001 \\
\hline Meslek odanız var mı? & $\begin{array}{l}\text { Evet } \\
\text { Hayir } \\
\text { Bilmiyorum }\end{array}$ & $\begin{array}{l}29(25.2) \\
36(31.3) \\
50(43.5)\end{array}$ & $\begin{array}{l}22(23.2) \\
38(40) \\
35(36.8)\end{array}$ & $\begin{array}{l}23(24.5) \\
48(51) \\
23(24.5)\end{array}$ & $\begin{array}{l}7(11.7) \\
45(75) \\
8(13.3)\end{array}$ & 0.001 \\
\hline $\begin{array}{l}\text { Mesleğinizle ilgili bir dernek } \\
\text { var mı? }\end{array}$ & $\begin{array}{l}\text { Evet } \\
\text { Hayır } \\
\text { Bilmiyorum }\end{array}$ & $\begin{array}{l}97(84.3) \\
3(2.6) \\
15(13)\end{array}$ & $\begin{array}{l}84(88.4) \\
7(7.4) \\
4(4.2)\end{array}$ & $\begin{array}{l}83(88.3) \\
5(5.3) \\
6(6.4)\end{array}$ & $\begin{array}{l}56(93.3) \\
4(6.7) \\
0\end{array}$ & 0.01 \\
\hline $\begin{array}{l}\text { Mesleğinizin akreditasyonu var } \\
\text { mı? }\end{array}$ & $\begin{array}{l}\text { Evet } \\
\text { Hayır } \\
\text { Bilmiyorum }\end{array}$ & $\begin{array}{l}37(32.2) \\
11(9.6) \\
67(58.3)\end{array}$ & $\begin{array}{l}18(18.9) \\
19(20) \\
58(61.1)\end{array}$ & $\begin{array}{l}9(9.6) \\
44(46.8) \\
41(43.6)\end{array}$ & $\begin{array}{l}7(11.7) \\
21(35) \\
32(53.3)\end{array}$ & 0.001 \\
\hline
\end{tabular}

Fizyoterapi ve Rehabilitasyon Bölümü öğrencilerin BUÖ toplam skoru ile ilgili faktörler arası ilişki Tablo 5'de sunuldu. BUÖ ile cinsiyet arasinda ( $\mathrm{p}=0.002, \mathrm{r}=-0.15)$, BUÖ ile aile geliri arasında negatif ilişki bulundu $(\mathrm{p}=0.86 \mathrm{r}=-0.009)$. BUÖ ile mezun sayısının artışı, iş bulma kaygısı, mesleki saygınlık, tekrar tercih etme durumu ve bölüm memnuniyeti arasında anlamlı ilişki bulundu $(\mathrm{p}<0.05)$.

\section{Tartışma}

Fizyoterapi ve Rehabilitasyon Bölümü öğrencilerinin hafif umutsuzluk düzeyinde oldukları ve 2. siniftan itibaren umut düzeylerinin azaldığı görülürken, son sınıfa doğru ilerledikçe meslek ile ilgili sorulara verilen doğru cevap sayısının arttığı saptanmıştır. Araştırmaya katılan öğrencilerin çoğunluğu mezuniyet sonrası iş bulma endişesi yaşamaktadır ve bu endişe 4. sinıfa doğru ilerledikçe artış göstermektedir. Fizyoterapi ve Rehabilitasyon Bölümü öğrencilerinde, umutsuzluk düzeyi ile cinsiyet, sosyoekonomik düzey, mesleki kayg1 ve bölüm memnuniyetinin ilişkili olduğu görülmüştür. Farklı örneklem gruplarında umutsuzluk düzeyi ile cinsiyet farklılığı arasındaki ilişkiyi araştırmaya yönelik yapılan çalışmaların bulgularının benzer olduğu görülmüştür $(5,15-17)$. Lise öğrencileri (15) ve üniversite öğrencilerinin (16) umutsuzluk düzeyini belirlemek amaciyla yapılan çalışmalarda erkek öğrencilerin kız öğrencilere göre umut düzeylerinin daha düşük olduğu bulunmuştur. Çalışmamızda da cinsiyet ile umutsuzluk düzeyi arasındaki istatistiksel olarak anlamlı ilişki olduğu görülmüştür. Literatür ile uyumlu olarak cinsiyetin umut düzeyleri üzerine etki ettiğini düşünmekteyiz. Türkiye İstatistik Kurumu'nun 2017 y1lında yayınladığı 24643 sayılı "İstatistiklerle Kadın, 2016" başlıklı haber bülteninde, Türkiye'de 15 ve daha yukarı yaştaki nüfus içerisinde Genç işsizlik oranının \%18,5 olmakla birlikte bu oranın erkeklerde \%16.5, kadınlarda ise $\% 22.2$ olduğunu belirtmiştir (18). Kadınlarda işsizlik 
oranının daha yüksek olmasına rağmen çalışmamızda erkek öğrencilerin kız öğrencilere göre umut düzeylerinin daha düşük olması toplumumuzda erkeklerin aile geçimini sağlamakta daha fazla rol üstlenmesi ile ilişkilendirilebilir. $\mathrm{Bu}$ nedenle, diğer çalışmalarda da belirtildiği gibi erkeklerin kadınlara oranla iş bulma konusunda daha fazla endişeye sahip olması ve umutsuzluğu kapılması beklenen bir durumdur (15-17).

Tablo 3. Öğrencilerin Mesleki Kayg1, Mesleki Yeterlilik ve Mesleki Memnuniyet İle İlgili Sorulara Verilen Cevapların Dağılımı

\begin{tabular}{|c|c|c|c|c|c|}
\hline & $\begin{array}{c}\text { 1. Sinif } \\
(\mathrm{n}=115) \\
\mathrm{n}(\%)\end{array}$ & $\begin{array}{c}\text { 2. Sinif } \\
\begin{array}{c}(\mathrm{n}=95) \\
\mathrm{n}(\%)\end{array}\end{array}$ & $\begin{array}{c}\text { 3. Sinıf } \\
(\mathrm{n}=94) \\
\mathrm{n}(\%)\end{array}$ & $\begin{array}{c}\text { 4. Sinıf } \\
(n=60) \\
n(\%)\end{array}$ & $\mathrm{p}$ \\
\hline $\begin{array}{c}\text { İş bulma kaygısı } \\
\text { Kaygılı değilim } \\
\text { Biraz kaygılıyım } \\
\text { Kaygılıyım } \\
\text { Çok kaygılıyım } \\
\text { Bilmiyorum }\end{array}$ & $\begin{array}{l}14(12.2) \\
34(29.6) \\
49(42.6) \\
15(13) \\
3(2.6)\end{array}$ & $\begin{array}{l}15(15.8) \\
46(48.4) \\
27(28.4) \\
7(7.4) \\
0()\end{array}$ & $\begin{array}{l}13(13.8) \\
45(47.9) \\
26(27.7) \\
8(8.5) \\
2(2.1)\end{array}$ & $\begin{array}{l}10(16.7) \\
16(26.7) \\
19(31.7) \\
13(21.7) \\
2(3.3)\end{array}$ & 0.01 \\
\hline $\begin{array}{l}\text { Mesleki saygınlık } \\
\text { Hayır düşünmüyorum } \\
\text { Biraz düşünüyorum } \\
\text { Düşünüyorum } \\
\text { Çok düşünüyorum } \\
\text { Bilmiyorum }\end{array}$ & $\begin{array}{l}55(47.8) \\
41(35.7) \\
13(11.3) \\
3(2.6) \\
3(2.6)\end{array}$ & $\begin{array}{l}55(57.9) \\
22(23.2) \\
13(13.7) \\
1(1.1) \\
4(4.2)\end{array}$ & $\begin{array}{l}51(54.3) \\
29(30.9) \\
12(12.8) \\
1(1.1) \\
1(1.1)\end{array}$ & $\begin{array}{l}43(71.7) \\
13(21.7) \\
3(5) \\
0 \\
1(1.7)\end{array}$ & 0.14 \\
\hline $\begin{array}{l}\text { Mesleki yeterlilik } \\
\text { Yeterli değilim } \\
\text { Biraz yeterliyim } \\
\text { Yeterliyim } \\
\text { Çok yeterliyim } \\
\text { Bilmiyorum }\end{array}$ & $\begin{array}{l}29(25.2) \\
43(37.4) \\
17(14.8) \\
5(4.3) \\
21(18.3)\end{array}$ & $\begin{array}{l}36(37.9) \\
38(40) \\
11(11.6) \\
3(3.2) \\
7(7.4)\end{array}$ & $\begin{array}{l}17(18.1) \\
49(52.1) \\
15(16) \\
7(7.4) \\
6(6.4)\end{array}$ & $\begin{array}{l}13(21.7) \\
22(36.7) \\
21(35) \\
3(5) \\
1(1.7)\end{array}$ & 0.001 \\
\hline $\begin{array}{l}\text { B } \\
\text { ölümünüzü tekrardan seçer } \\
\text { misiniz? } \\
\\
\text { Kesinlikle hayır } \\
\text { Hayır } \\
\text { Evet } \\
\text { Kesinlikle evet } \\
\text { Bilmiyorum }\end{array}$ & $\begin{array}{l}23(20) \\
39(33.9) \\
21(18.3) \\
10(8.7) \\
22(19.1)\end{array}$ & $\begin{array}{l}16(16.8) \\
24(25.3) \\
26(27.4) \\
13(13.7) \\
15(15.8)\end{array}$ & $\begin{array}{l}22(23.4) \\
23(24.5) \\
28(29.8) \\
11(11.7) \\
10(10.6)\end{array}$ & $\begin{array}{l}18(30) \\
15(25) \\
10(16.7) \\
6(10) \\
11(18.3)\end{array}$ & 0.27 \\
\hline $\begin{array}{l}\text { Bölüm memnuniyeti } \\
\text { Memnun değilim } \\
\text { Biraz memnunum } \\
\text { Memnunum } \\
\text { Çok memnunum } \\
\text { Bilmiyorum }\end{array}$ & $\begin{array}{l}34(29.6) \\
51(44.3) \\
19(16.5) \\
6(5.2) \\
5(4.3)\end{array}$ & $\begin{array}{l}17(17.9) \\
39(41.1) \\
31(32.6) \\
5(5.3) \\
3(3.2)\end{array}$ & $\begin{array}{l}26(27.7) \\
32(34) \\
24(25.5) \\
7(7.4) \\
5(5.4)\end{array}$ & $\begin{array}{l}24(40) \\
20(33.3) \\
11(18.3) \\
2(3.3) \\
3(5)\end{array}$ & 0.15 \\
\hline
\end{tabular}

Üngören ve Ehtiyar'ın Türk ve Alman Öğrencilerin umutsuzluk düzeylerini karşılaştırdıkları ve umutsuzluk düzeylerini etkileyen faktörleri araştırdıkları çalışmalarında ailelerinin maddi imkânı düşük olan öğrencilerin umutsuzluk düzeylerinin daha yüksek olduğu bulunmuştur (19). Devlet ve vakif üniversitesinde öğrenime devam eden öğrencilerin umutsuzluk düzeylerine etki eden faktörlerin araștırıldığı diğer bir çalıșmanın sonuçlarına göre devlet üniversitesinde okuyan öğrencilerin umutsuzluk düzeyi daha yüksektir (20). Bizim çalışmamızda da benzer olarak aile gelir düzeyi ile umut arasında istatistiksel anlamlı negatif bir ilişki bulunmuştur. Öğrencilerin ailesinin maddi gelir düzeyi arttıça umutsuzluk düzeylerinin azaldığı saptanmıştır. Günümüzde birçok üniversite öğrencisi aldıkları eğitimi yeterli görmemekte ve mezuniyet sonrasında iyi bir işte çalışmak için mesleki ve kişisel gelișimine yönelik özel eğitimler almak istemektedir. Öğrencilerin kongre, sempozyum, 
seminer, dil okulu ve benzeri olanaklar aracılığ ile kendilerini geliştirmeleri konusunda ailelerinin maddi desteğine ihtiyacı vardır. $\mathrm{Bu}$ nedenle; öğrencilerin eğitim için ailelerinden yeterli maddi destek alamamaları kendilerini geliştirmek için motivasyonlarının azalmasına ve geleceğe daha umutsuz bakmalarına sebep olmaktadir.

Tablo 4. Öğrencilerin Beck Umutsuzluk Ölçeği ile ilgili faktörlerin ilişkisinin incelenmesi

\begin{tabular}{lll}
\hline & \multicolumn{2}{l}{$\begin{array}{l}\text { Beck Umutsuzluk } \\
\text { Toplam Skoru }\end{array}$} \\
\hline Yaş & $\mathrm{r}=0.06 \quad \mathrm{p}=0.25$ \\
Cinsiyet & $\mathrm{r}=0.15^{* *} \mathrm{p}=0.002$ \\
Sinıf & $\mathrm{r}=0.08 \quad \mathrm{p}=0.12$ \\
Medeni durum & $\mathrm{r}=0.01 \quad \mathrm{p}=0.73$ \\
Aile Geliri & $\mathrm{r}=-0.009^{*} \mathrm{p}=0.86$ \\
Tercih Sırası & $\mathrm{r}=0.07 \quad \mathrm{p}=0.13$ \\
Kontenjan Artışı & $\mathrm{r}=-0.01 \quad \mathrm{p}=0.76$ \\
Mezun Sayıs1 & $\mathrm{r}=-0.11^{*} \quad \mathrm{p}=0.03$ \\
İstihdam Sayıs1 & $\mathrm{r}=0.06 \mathrm{p}=0.19$ \\
Eğitim Süresi & $\mathrm{r}=-0.05 \mathrm{p}=0.30$ \\
İş Bulma Kaygıs1 & $\mathrm{r}=0.22^{* *} \mathrm{p}=0.001$ \\
Mesleki Saygınlık & $\mathrm{r}=-0.13^{* *} \mathrm{p}=0.009$ \\
Mesleki Yeterlilik & $\mathrm{r}=-0.10 \mathrm{p}=0.05$ \\
Tekrar tercih etme & $\mathrm{r}=-0.19^{* *} \mathrm{p}=0.001$ \\
durumu & \\
Memnuniyet & $\mathrm{r}=-0.24 \mathrm{p}=0.001$ \\
\hline
\end{tabular}

Artan mezun sayısı, iş bulma kaygısı ve mesleki saygınlığın azaldığı düşünceleri Fizyoterapi ve Rehabilitasyon öğrencilerinde umutsuzluk düzeyini etkileyen diğer faktörlerdir. Artan mezun sayısı ile birlikte mesleki saygınlığın azaldığı düşüncesi ve iş bulması kaygısının artması öğrencilerin mesleki gelecekleri konusunda karamsar hissetmelerine neden olmaktadır. Buna göre, mesleki gelecekleri konusunda karamsar olan öğrencilerin umutsuzluk düzeylerinin de artmakta olduğu söylenebilir. Üniversite öğrencilerindeki umutsuzluğun yükselmesinin nedenleri olarak gelişmekte olan bir ülke olan Türkiye'de üniversiteli işsiz sayısının artması, iş bulamama korkusu ve ekonomik kaygılar gösterilmiştir (8,
21, 22). Bir diğer önemli durum, Fizyoterapi ve Rehabilitasyon eğitimi veren okulların günden güne artan say1 ve kontenjanları ile artan mezun sayısını karşılamakta yetersiz kalan istihdam koşullarının beraberinde rekabeti ve işsizliği getirmesidir. Öğrenciler, sınıfları ilerledikçe bir meslek sahibi olma ve mesleklerini uygulama konusunda gerçekler ile karşılaşmaya başlamaları nedeniyle son sınıf öğrencilerinin iş bulma kaygı düzeyleri daha yüksektir. $\mathrm{Bu}$ iş bulma kaygisı umutsuzluğunun daha da artmasina neden olmaktadır.

Öğrencilerin eğitim almış oldukları bölümden memnun olmamaları onların umutsuzluk düzeylerini arttırmaktadır. Yapılan bir çalışmada hem Türk hem Alman öğrencilerde eğitim memnuniyeti ile umutsuzluk düzeyleri arasında istatistiksel olarak anlamlı ilişki olduğu saptanmıştır(19). Bizim çalışmamızda bölüm memnuniyetinin 1. sinifta $\% 16.5,2$. sinifta $\% 32.6,3$.sinıfta $\% 25.5$ ve 4 . sinıfta $\% 18.3$ olduğu ve umut düzeylerinin de memnuniyet ile negatif ilişkili olduğu görülmüştür. Aynı zamanda, tekrar tercih etme durumu ile umutsuzluk düzeyi ilişkili bulunmuştur. Bölümlerinden memnun olmayan ve tekrar tercih etmeyi düşünmeyen öğrencilerin umutsuzluk puanı daha yüksektir. Eğitim aldıkları bölümden memnun olmamak öğrencilerin gelecekleri hakkında olumsuz düşüncelere kapılmasına, geleceğe umutsuz bakmasına, motivasyonlarının azalmasına ve umutsuzluk düzeylerinin artmasina neden olmaktadır $(7,22)$.

Sonuç olarak, Fizyoterapi ve Rehabilitasyon bölümü öğrencilerinin mesleğe yönelik umutsuzluk yaşadıkları ve umutsuzluğa cinsiyet, aile gelir düzeyi, artan mezun sayısı, iş bulma endişesi, mesleki saygınlık, aldığ eğitimden memnun olmama gibi birçok faktörün etkili olduğu saptanmıştır. Umutsuzluk birçok fiziksel ve psikolojik rahatsızlıklara neden olabileceği için öğrencilerin umutsuzluk durumlarını belirlemek ve değiştirilebilir faktörler için önlem alabilmek gereklidir. Yeni mezun fizyoterapistlerin daha verimli ve kaliteli çalışabilmesi için hayata ve mesleklerine daha umutla bakabilmeleri sağlanmalıdır. Öğrencilerin akademik başarısının, mesleki yeterliliğinin ve memnuniyetinin arttırılması için öğretim elemanlarının desteğinin alınması gerektiği ve istihdam artışı ile orantılı olarak mezun verilmesinin iş bulma imkanlarını arttıracağı düşünmekteyiz. 


\section{Kaynaklar}

1. Lester D. Hopelessness in undergraduate students around the world: a review. J Affect Disord. 2013;150(3):1204-8.

2. Lester D. Hopelessness in adolescents. J Affect Disord. 2015;173:221-5.

3. Dilbaz N, Seber G. Umutsuzluk kavrami: Depresyon ve intiharda önemi. Kriz Dergisi. 1993;1(3):134-8.

4. Özdel L, Bostancı M, Özdel O, Oğuzhanoğlu NK. Üniversite öğrencilerinde depresif belirtiler ve sosyodemografik özelliklerle ilişkisi. Anadolu Psikiyatri Dergisi. 2002;3(3):155-61.

5. Şahin C. Eğitim fakültesinde öğrenim gören öğrencilerin umutsuzluk düzeyleri. Selçuk Üniversitesi Ahmet Keleşoğlu Eğitim Fakültesi Dergisi. 2009;27:271-86.

6. Kilıç Sibel, Tektaş Necla, Tuba P. Devlet Ve Vakif Meslek Yüksekokulu Öğrencilerinin Umutsuzluk Düzeylerinin Karşilaştirilmasi Ve Umutsuzluk Düzeylerini Etkileyen Faktörlerin Belirlenmesi. Türkiye Sosyal Araştırmalar Dergisi. 2014;182(182):169-86.

7. Gündoğar D, Gül SS, Uskun E, Demirci S, Keçeci D. Üniversite öğrencilerinde yaşam doyumunu yordayan etkenlerin incelenmesi. Klinik Psikiyatri. 2007;10(1):14-27.

8. Aydın M, Erdoğan S, Yurdakul M, Eker A. Sağlık yüksekokulu ve sağlik meslek lisesi öğrencilerinin umutsuzluk düzeyleri. SDÜ Sağlık Bilimleri Dergisi. 2013;4(1):1-6.

9. Oğuztürk Ö, Akça F, Şahin G. Üniversite öğrencilerinde umutsuzluk düzeyi ile problem çözme becerileri arasındaki ilişkinin bazı değişkenler üzerinden incelenmesi. Klinik Psikiyatri. 2011;14:173-84.

10. Yalçın S, Açıkgöz İ. Sağlık Bilimleri Fakültesi Son Sınıf Öğrencilerinin Umutsuzluk Düzeylerinin Karşılaştırılması. Mustafa Kemal Üniversitesi Sosyal Bilimler Enstitüsü Dergisi. 2014;11(26): 259-70.

11. Beck AT, Weissman A, Lester D, Trexler L. The measurement of pessimism: the hopelessness scale. J Consult Clin Psychol. 1974;42(6):861-5. 12. Durak A. Palabıyıkoğlu R. Beck Umutsuzluk Ölçeği geçerlilik çalışması. Kriz Dergisi. 1994;2(2):311-9.

13. Seber G, Dilbaz N, Kaptanoğlu C, Tekin D. Umutsuzluk ölçeği: Geçerlilik ve güvenirliği. Kriz Dergisi. 1993;1(3):139-42.

14. Beck A, Steer R. Manual for the Beck hopelessness scale. San Antonio, TX: Psychological Corporation. 1988.
15. Özmen D, Dündar PE, Çetinkaya AÇ, Taşkın $\mathrm{O}$, Özmen E. Lise öğrencilerinde umutsuzluk ve umutsuzluk düzeyini etkileyen etkenler. Anadolu Psikiyatri Dergisi. 2008;9(1):8-15.

16. Cam Celikel F, Erkorkmaz U. Üniversite Öğrencilerinde Depresif Belirtiler ve Umutsuzluk Düzeyleri ile İlişkili Etmenler. Noropsikiatri Arsivi. 2008;45(4):122-9.

17. Erdoğdu Y. Kişisel ve sosyal uyum düzeylerinin öğretmen adaylarının umutsuzluk düzeylerini yordaması. Eğitim ve Öğretim Araştırmaları Dergisi, 1. 2012;2:123-34.

18. Türkiye İstatistik Kurumu. "İstatistiklerle Kadın, 2016".2017;www.tuik.gov.tr.

19. Üngüren E, Ehtiyar R. Türk ve Alman öğrencilerin umutsuzluk düzeylerinin karşılaştırılması ve umutsuzluk düzeylerini etkileyen faktörlerin belirlenmesi: turizm eğitimi alan öğrenciler üzerinde bir araştırma. Journal of Yasar University. 2009;4(14):2093-127.

20. Kılıç S, Tektaş N, Pala T. Devlet ve Vakıf Meslek Yüksekokulu Öğrencilerinin Umutsuzluk Düzeylerinin Karşış̧̧ırılması ve Umutsuzluk Düzeylerini Etkileyen Faktörlerin Belirlenmesi. Türkiye Sosyal Araştırmalar Dergisi. 2014;18(2):169-86.

21. Dereli F, Kabataş S. Sağlık yüksekokulu son sınıf öğrencilerinin iş bulma endişeleri ve umutsuzluk düzeylerinin belirlenmesi. Yeni Tip Dergisi. 2009;26(1):31-6.

22. Gençay S. Beden eğitimi öğretmeni adaylarının umutsuzluk ve yaşam doyumlarının bazı değişkenler açısından incelenmesi. Elektronik Sosyal Bilimler Dergisi. 2009;8(27):380-8. 